\title{
The Kazakhstan Biotechnologies in Environmental Protection: State and Prospects
}

\section{Bakhyt Mynbayeva*¹, Nina Voronova ${ }^{2}$, Karlygash Musdybayeva ${ }^{1}$, Bakhytkul Amirasheva $^{3}$, Laura Seilova ${ }^{1}$, Saule Dzhamilova ${ }^{1}$}

\author{
${ }^{1}$ Kazakh National Pedagogical University named after Abai, av. Dostyk, 13, Kazakhstan, Almaty, \\ ${ }^{2}$ Kazakh National University named after al-Farabi, Timiryazev st., 72, Kazakhstan, Almaty, \\ ${ }^{3}$ Institute of Microbiology and Virology, Borenbai batyr st., 103, Kazakhstan, Almaty, \\ 1*bmynbayeva@gmail.com, ${ }^{1}$ mkk77@mail.ru, ${ }^{1}$ sauka70@mail.ru \\ 2slovonine@mail.ru, ${ }^{3}$ bahitka_85@mail.ru
}

\begin{abstract}
Kazakhstan has some territories contaminated by radionuclides, oil products, heavy metals, and etc. However, the authors of the mini-survey showed a poor development of biotechnological researches aimed at solving the ecological problems. In Kazakhstan a greater development of biotechnologies lies in the fields of medicine, agriculture, plants bioengineering, immunological and molecular genetic diagnostics, prevention of highly dangerous animal diseases, and etc. The main biotechnology researches in environmental protection are performed only by individual organizations, which are National Center of Biotechnology, Institute of Microbiology and Virology, some universities and research institutes. For example, Kazakhstani scientists used the soil hydrocarbon oxidizing microorganisms to recover oil-contaminated areas; isolated from environment the Gramineae that has high accumulative properties for heavy metals and pesticides; created a production of bioethanol, and etc. The given examples of the developed biotechnologies improved environment's condition. However, environmental biotechnology tools usually are being developed separately, do not have Coordination Centre, and mainly aimed at water and soil purification from heavy metals and petroleum products. Also they are focusing on creation of biological methods for the natural components recovery. Thus, the highly efficient biotechnologies in the field of environment protection and its degradation in Kazakhstan is the issue of further prospects.
\end{abstract}

Keywords: biological technology, environment, Kazakhstan.

Biotechnology is usually determined as the direction of scientific and technological progress, which uses biological objects and bioprocesses to produce useful products for human beings, maintain and improve life quality. As for the life environment, it is well known that at the current stage of development of civilization a global potential threat of adverse environmental changes for human and biota takes the place. The Republic of Kazakhstan is not an exception.

The humankind seeks to sustainable development of civilization, highlight of which is the protection of the environment in different ways: economic (the conservation of natural resources and their careful use), social, political, and environmental (protection of ecosystems). Real defensibility is the usage of biotechnology, which is oriented on the air, water and soil safety from industrial and agricultural pollution.

The purpose of this article: to show the development of biotechnology in Kazakhstan, aimed to resolve environmental problems.

The results of investigations, carried out under the auspices of UNDP, UNEP, OBSE [1, 2], showed that in Kazakhstan due to high environmental risk insecure regions for human habitation are in existence, for example, Semipalatinsk, Aktau and the surrounding areas, the Caspian and Aral Seas and the surrounding areas, the Irtysh river (Kazakhstan, Russia), etc. The most serious problems are related to drinking water and the presence of badly engineered landfill radioactive waste [3-6].

What is the role of biotechnology developments in solving these problems in the Republic of Kazakhstan?

At first, we should divide biotechnology as a science and industrial biotechnology. We will not analyze the state of biotechnology in Kazakhstan as a science; we are referring to biotechnology implementation. 
This article contains preliminary selection of biotechnologies currently working out in Kazakhstan. It also attempts to analyze biotechnological techniques and biological development that are aimed to protect the environment. A selection is based on information from the National Center of Biotechnology (NCB, Astana city), Kazakhstan's scientific research institutes (SRI), own research of primary author and his colleagues studies.

As a result of comparative selection turned out that the best biotechnology is represented in medicine, which has been developing in the NCB since 1993. For example, were obtained or developed:

- cell culture of human embryonic fibroblasts for extensive and deep 3-4 $4^{\text {th }}$ degree burns treatment;

- total cement-free hip replacement;

- molecular approaches to drug administration based on genetic data of the individual patient by using two test systems;

- basics of getting and application of stem cells;

- first domestic test systems to determine the hepatitis viruses B and C.

Also in NCB received the following medicine drugs: "Erythropoietin" in the form of tablets for patients with anemia, "Ferim" to burns, "Bifidumbacterin", "Ekobak" for soil decontamination from oil pollution, "Bioturin" and "Bitoksiturin" for pest management, etc. [7].

There is a development a biotechnology in Kazakhstan's agriculture in evidence. For example, in $\mathrm{NCB}$ on the basis of bio-engineering (with the improvement of the gene pool) new promising varieties of wheat, potatoes, barley with resistance to disease and drought were obtained. Also effective methods of immunological and molecular-genetic diagnosis and prevention of high-risk animal diseases were developed, their production and sales, too.

In laboratory of DNA animal testing called "Kazakh tulpars" (Kostanai city) the similar problems are solved: a new breed of horses has been derived - the Kazakh Saddle Horse. In the Kazakh SRI of fruit growing and viticulture (Almaty city) was developed the molecular biotechnology of the grape's micro clonal propagation in vitro and was received free from the viral and mycoplasma infections grape's planting material.

We want to refer more closely to the biotechnology development in environmental protection. There are some examples of the indirect influence of biotechnology developed in NCB on the environment, especially, to protect the of soil cover. NCB employees are produced the bio-pesticides on the basis of living microorganisms - viruses, bacteria, fungi, that lead to mass death of "bad" insects through infectious diseases. These biologics are not harmful to the environment and safe for humans.

Thus, replacement of chemical preparations on the biologics will reduce of environment contamination.

Development of bio-humus and bio-fertilizers in Kazakhstan on the basis of organic residues and various types of beneficial soil microorganisms is valuable in terms of improving environmental conditions. It is not only promotes the crop yields, but also improve the quality of soil cover [8].

It should be noted a development of bioethanol production in Kazakhstan, the use of which solves both energy and environmental problems. At burning of bioethanol is much reduced the atmospheric emissions compared to petrol. However, ethanol production is carried out due to foreign existing technologies, which are adapted to the local raw materials.

The National Center Biotechnology scientists created biologics based on hydrocarbon-oxidizing microorganisms for the cleaning up soils, covering the oil, in Karaganda, Atyrau and Mangistau regions: 32 thousand tons of soil was purified, purification efficiency was 97\% during 2 months.

Other scientists have been developed the apparatus for biological purification of oil contaminated areas (the Center of Chemical-Technological Studies). The carried out researches showed the high efficiency of the apparatus, as after a short time on cleared land grew the meadow grass already $[9$, $10]$.

Some time ago more important environmental protection investigations were held in the Institute of Microbiology and Virology (Kazakhstan, Almaty city). B. Mynbayeva et al. were obtained the microbial strains, by means of which it was possible to purify waste water from a toxic arsenic compounds, during the 80-s of XX century. As a result, they had received 2 certificates of authorship $[11,12]$. 
At present the main directions of scientific activity of the Institute of Microbiology and Virology are:

- study of the microbiological transformations' mechanisms of metals and development of the technology environment's bioremediation by using microorganisms;

- development of microbial means of plant protection from infectious diseases of different nature;

- and much more, including virologic investigations.

It should be noted that the Institute of Microbiology and Virology remains actively seized of bioremediation environmental technologies using microorganisms. It is now one of the main directions of the Institute of Microbiology and Virology scientific activity is the development of technologies and bacterial preparations for microbiological purification of water bodies, soil and industrial wastewater from oil pollution [13, 14].

Similar studies were conducted in Kazakh National University named after al-Farabi related to cleaning the ladder track's ballast stone from oil contamination [15].

Scientists from the Institute of Biology and Plant Biotechnology (Kazakhstan, Almaty city) isolated from environment grains with a high accumulative properties for heavy metals and pesticides, i.e. their usage in environment clearance is very forward-looking by bringing them to the superaccumulation level through biotechnological methods [16, 17].

Already B. Mynbayeva et al. received a patent for phytoremediation method of soil clearance from heavy metals in 2010 [18]. In this study, our purpose was to estimate the possibility of using Perennial rye grass Lolium perenne $\mathrm{L}$. seedlings to assess the toxicity of Almaty city soils in model experiments on the inhibitory effect of serial doses of heavy metals (HMs) on ecophysiological characteristics of plant growth and development. The obtained results characterize L. perenne as a test plant with a high indicator value with respect to HMs, which allows it to be used not only for phyto-monitoring but also in diagnostic studies, with a 50\% reduction in certain parameters of its growth and development being indicative of soil $\mathrm{Cd}$ or $\mathrm{Pb}$ concentrations toxic for plants. Suppression of these parameters was also observed in experiments with other HMs. For example, $\mathrm{EC}_{20}$ was recorded in 16 cases (in particular, for the stem and root length in experiments with $\mathrm{Cu})$; threshold toxicity $\left(\mathrm{EC}_{10}\right)$ was observed mainly in experiments with $\mathrm{Zn}$. In general, these metals appear to be less toxic for L. perenne than $\mathrm{Pb}$ and $\mathrm{Cd}$. On the basis of model experiments with soils supplemented by $\mathrm{Cd}, \mathrm{Pb}, \mathrm{Cu}$, and $\mathrm{Zn}$, we conclude that L. perenne is a highly effective indicator plant whose physiological and ecotoxicological parameters can be used to determine the degree of soil pollution with HMs.

At present, B. Mynbayeva et.al. received a patent for assessing the toxicity of urban soils contaminated with heavy metals by using a bacterial strain Azotobacter chroococcum (Beijerinck 1901). The degree of urban soils toxicity can be determined by decrease of 3 growth and development indexes of bacteria strain [19].

Thus, the National Center Biotechnology carries out major biotechnology studies, new technologies and material resources implementation in biotechnological production. It also coordinates fundamental and applied researches in this area.

In general, we can say that biotechnological achievements covered medical and agricultural sectors of the state's economy, where it is possible to develop genetic engineering of animals, plants, in order to receive new varieties. Besides of the NCB, Institute of biological safety issues (Gvardeysky, Zhambyl region), Institute of industrial biotechnology (Stepnogorsk city) and others conduct biotechnology researches, but more narrowly. Also, it is very noticeable that practically all the Kazakhstan's companies and enterprises are trying to buy western technology without regard for local scientist's achievements.

Hence, biotechnologies, aimed directly to safety or environmental protection are being developed separately. They do not have a focal center, and mainly related to purification of water or soils from heavy metals and petroleum products. Thus, creation of highly effective biotechnologies to prevent the degradation of the environment is in the future.

Based on my own knowledge and experience, the authors of the article recommend leading the biotechnology researchers on the basis of university's laboratories on specific orders of the Ministry of Environment and Water Resources of Kazakhstan or the research orders of private companies that have problems with environment. The fact of the matter is that, in the given process may be involved students, undergraduates and doctoral candidates. 
And at the end of education training, it is possible to give them recommendation letters to companies that cooperated with the university. So we can avoid a sad statistics that no more than 5-7 persons of approximately 500 annual graduates of biological faculties come into work in research institutes, i.e. there is no one to perform laboratory assistance work.

Moreover, university students, while learning to perform scientific works, can help in researches and development. At the Universities, where we work, there is a vocational guidance for teaching staff trainings, so the approach, mentioned above, may not be effective. But other universities, for example, Kazakh National University named after al- Farabi, Kazakh National Agricultural University, etc. on the basis of laboratories can carry out such researches, especially when university teaching staff includes scientists from different research institutions.

The another evidentiary example: in former Soviet Union, Veterinary Institute (now a part of Kazakh National Agricultural University) has produced vaccines for farm animals, and continues to produce it now.

Also, it is possible to enhance international cooperation pertaining to development and implementation of biotechnological solutions in environmental protection, as part of some pilot projects, and establish an international program "Biotechnology for the environment". Moreover, it should be kept in mind that it is necessary to create in Kazakhstan its own biotech industry, where authoring will be implemented [20]. It will make economic and ecological contribution to the environmental protection.

Unfortunately, environment protection and conservation is not a top-priority goal for Kazakhstan, in comparison with such serious problems as, for example, researches on tuberculosis prevention, cancer, desertification, water conservation, development of alternative energy sources.

We think that, of course, these problems are very important, but while developing biotechnology for environmental protection, we work as for "today", but for "tomorrow" as well. Consequently, Kazakhstan need to enable environmental protection in the list of top country's priorities and form a government orders for biologists and biotechnologists, creating biotechnology cluster for researches and development in this area.

We would most like to enhance a process of cooperation on a level of scientific partnerships in order to develop biotechnologies in XXI century, focusing on interdependence between protection of the environment, safety of living in it and biotechnology requirements and opportunities, to establish a network of contacts between stakeholder groups on the national level in Kazakhstan and abroad in order to promote the environmental cooperation.

\section{REFERENCES}

[1] UNDP 2003: Addressing Environmental Risks in Central Asia. Risks, Conditions, Policies, Capacities, Bratislava: United Nations Development Programme.

[2] Materialy 5-j Pan-Evropejskoj konferencii «Okruzhajushhaja sreda dlja Evropy»: Sekcija 12 «Okruzhajushhaja sreda», maj 2002. - Kiev: UNEP, izd-vo General'naja Assambleja. - 2002. (In Russ.) .

[3] Kenley Butler. Weapons of Mass Destruction in Central Asia, Nuclear Threat Initiative (NTI). Washington DC: October 2002. http://nti.org/e_research/e3_19a.html. 2002. Last accessed 15.02.2016.

[4] National States of Environment reports (SoE) for all countries of Central Asia, http://www.grida.no/aral/main_e.htm. Last accessed 25.01.2016.

[5] Materialy Soveshhanija po okruzhajushhej srede, vode i bezopasnosti v Central'noj Azii. Almaty: Central'noaziatskijregional'nyj jekologicheskij centr, 30-31 janvarja, 2003 g. (In Russ.).

[6] http://www.grida.no/enrin/htmls/tadjik/soe2001/rus/. Last accessed 25.01.2016. (In Russ.).

[7] http://www.kazpravda.kz/c/1170286128. Last accessed 25.01.2016. (In Russ.).

[8] http://www.kazpravda.kz/c/1349313242. Last accessed 25.01.2016. (In Russ.).

[9] http://www.zakon.kz/4462316-v-kazakhstane-razrabatyvajutsja-novye.html.Lastaccessed 25.01.2016. (In Russ.).

[10] http://articles.gazeta.kz/art.asp?aid=71660. Last accessed 25.01.2016. (In Russ.). 
[11] B.N. Mynbayeva et al., "Shtamm bakterij Ps. putida, okisljajushhih soedinenija trehvalentnogo mysh'jaka i prednaznachennyj dlja ochistki stochnyh vod". USSA. Patent 844630, Jule 25, 1981 (In Russ.).

[12] B.N. Mynbayeva et al., "Sposob ochistki stochnyh vod ot mysh'jaka (III)". USSA. Patent 916441, March 11, 1982 (In Russ.).

[13] A.K. Cadanov et al., "Shtamm bakterij Arthrobacter globiformis 24, ispol'zuemyj dlja ochistki pochvy ot nefti i nefteproduktov". Republic of Kazakhstan. Patent 025881, Jule 08, 2012 (In Russ.).

[14] A.K. Cadanov et al., "Konsorcium shtammov Arthrobacter globiformis 24, Arthrobacter terregens P-1, Arthrobacter sp. K-3, Candida tropicalis FS-4 AT, ispol'zuemyj dlja ochistki pochvy ot nefti i nefteproduktov". Republic of Kazakhstan. Patent 027568, Oct. 12, 2013(In Russ.).

[15] G.M. Tjulebaeva, N. Zhanshina, A.K. Tynalinm, "Sposob ochistki shhebenochnogo ballasta zheleznodorozhnogo puti ot neftjanogo zagrjaznenija". Republic of Kazakhstan. Patent 14818, Aug. 22, 2004 (In Russ.).

[16] Atabaeva S.D., Ocenka stepeni akkumuljacii tjazhelyh metallov dikimi vidami rastenij s tochki zrenija fitoremediacii zagrjaznennyh pochv, Biol. nauki Kazahstana, Pp. 79-81, N 3-4 (2004) (In Russ.).

[17] Sarsenbaev B.A., Nurzhanova A.A., Atabaeva S.D., Razrabotka tehnologii fitoremediacii okruzhajushhej sredy ot zagrjaznenija tehnogennogo proishozhdenija, Biotehnologija. Teorija i praktika, Pp. 223-228, N 1(2006). (In Russ.).

[18] B.N. Mynbayeva et al., "Fitoremediacionnyj sposob ochistki pochv ot tjazhelyh metallov". Republic of Kazakhstan. Patent 22700, Aug. 29, 2010 (In Russ.).

[19] B.N. Mynbayeva et al., "Shtamm bakterij Azotobacter chroococcum IMD-3, ispol'zuemyj dlja ocenki toksichnosti pochv". Republic of Kazakhstan. Patent 29529, Feb. 18, 2015 (In Russ.).

[20] http://www.nomad.su/?a=10-200602010017. Last accessed 11.01.14. (In Russ.). 